\title{
Pogotena Sehat: Bakti Sosial Pelayanan Vaksinasi Covid-19 Bagi Masyarakat
}

\author{
Desak Made Anggraeni ${ }^{1}$, Yohanis Umbu Kaleka1, Etheldreda Rosari Garung, ${ }^{1}$ Ferdinandus Bele \\ Sole², Engel Bertha H. Gena ${ }^{3}$ \\ ${ }^{1}$ Pendidikan Fisika, STKIP Weetebula, Indonesia. \\ 2 Pendidikan Guru Sekolah Dasar, STKIP Weetebula, Indonesia. \\ ${ }^{3}$ Pendidikan Bahasa Indonesia, STKIP Weetebula, Indonesia.
}

DOI: $\underline{10.29303 / \text { ujcs.v2i4.157 }}$

\section{Article Info}

Received: November 21, 2021

Revised: December 20, 2021

Accepted: December 26, 2021

\begin{abstract}
Abstrak: Tujuan kegiatan ini adalah bakti sosial untuk memberikan pelayanan vaksinasi Covid-19 bagi masyarakat di desa Pogotena - Kecamatan Loura, Kabupaten Sumba Barat Daya - NTT. Kegiatan ini dilaksanakan atas kerjasama STKIP Weetebula dengan panitia bantuan vaksinasi Covid-19 Nasional dan juga Salim Group (Indofood, Indomaret, ACA Asuransi) serta Kemeterian Kesehatan Republik Indonesia. Pelaksana kegiatan ini oleh tim dosen dari STKIP Weetebula yang terdiri dari 3 dosen dari program studi pendidikan fisika, 1 dosen dari PGSD, dan 1 dosen dari program studi pendidikan Bahasa Indonesia dengan melibatkan 6 orang mahasiswa. Hasil dari kegiatan ini, yaitu: sebanyak 156 orang warga masyarakat di desa Pogotena dapat terlayani untuk vaksinasi dengan menggunakan jenis vaksin Astrazaneca. Beberapa kendala yang dihadapi di lapangan adalah banyak masyarakat yang harus pulang karena tidak memenuhi syarat untuk vaksin, seperti tekanan darah yang tinggi, jenis vaksin yang digunakan hanya Astrazaneca sehingga tidak bisa menjangkau masyarakat yang umurnya dibawah 18 tahun, dan juga pelayanan untuk masyarakat yang akan melakukan vaksin kedua karena jenis vaksin yang digunakan berbeda dengan jenis vaksin yang tersedia. Kesimpulan dari kegiatan bakti sosial ini adalah masyarakat sangat senang terhadap pelayanan dari dosen-dosen dan mahasiswa dan sangat berharap kegiatan ini dapat dilakukan lagi bagi warga yang belum memenuhi syarat untuk vaksin. Dengan kegiatan bakti sosial ini proses vaksinasi Covid-19 dapat dipercepat sehingga mewujudkan masyarakat dan desa yang sehat.

Kata Kunci: Bakti Sosial; Vaksinasi Covid-19; Masyarakat; Desa Pogotena.

Abstract: The purpose of this activity is social services to provide Covid-19 vaccination services for people in Pogotena village - Loura Subdistrict, Southwest Sumba Regency - NTT. This activity was carried out in collaboration with STKIP Weetebula with the National Covid-19 vaccination assistance committee and also Salim Group (Indofood, Indomaret, ACA Insurance) and the Health Ministry of the Republic of Indonesia. The implementation of this activity by a team of lecturers from STKIP Weetebula consisting of three lecturers from the physics education study program, 1 lecturer from PGSD, and 1 lecturer from the Indonesian education study program involving six students. The result of this activity, namely: as many as 156 people in pogotena village can be served for vaccination using astrazaneca vaccine type. Some of the obstacles faced in the field are that many people have to go home because they do not qualify for vaccines, such as high blood pressure, the type of vaccine used only Astrazaneca so that it cannot reach people under the age of 18 years, and also services for the community who will do the second vaccine because the type of vaccine used is different from the type of vaccine available. The conclusion of this social service activity is that the community is very happy with the services of lecturers and students and very hopeful that this activity can be done again for residents who have not qualified for vaccines. With this social service activity, the Covid-19 vaccination process can be accelerated so as to realize healthy communities and villages.

Keywords: Social Services; Covid-19 vaccination; Society; Pogotena Village.
\end{abstract}

Citation: $\quad$ Desak, A., Kaleka, Y.U., Garung, E.R., Sole, F.B., \& Gena, E. B. H. (2021). Pogotena Sehat: Bakti Sosial Pelayanan Vaksinasi Covid-19 Bagi Masyarakat. Unram Journal of Community Service, 2(4), 111-115. https://doi.org/10.29303/ujcs.v2i4.157 


\section{Pendahuluan}

Pada bulan Desember 2019, dunia dikejutkan dengan adanya virus baru yang kita kenal dengan nama corona virus 19 (Covid-19). Penyakit yang disebabkan oleh Covid-19 ini pertama kali ditemukan di Wuhan - China pada Desember 2019. Penyebaran virus ini sangat cepat ke seluruh dunia sehingga mengakibatkan pandemik Covid-19. Organisasi Kesehatan Dunia (WHO) mendeklarasikan wabah koronavirus 2019- 2020 sebagai Kesehatan Masyarakat Darurat Internasional (PHEIC) pada 30 Januari 2020, dan pandemi pada 11 Maret 2020.

Pandemik ini melanda hampir 200 negara di dunia termasuk Indonesia. Berbagai upaya dilakukan oleh pemerintah di berbagai Negara untuk memutus rantai penyebaran Covid-19 ini, mulai dari lockdown, social distancing sampai pada kegiatan PPKM. Usaha tersebut masih belum bisa membantu dalam mengatasi wabah Covid-19 ini. Langkah selanjutnya yang dilakukan oleh pemerintah untuk menekan kasus yang terus bertambah akibat Covid-19 adalah menganjurkan pemberian vaksin Covid-19 kepada seluruh warga masyarakat. Vaksinasi atau imunisasi bertujuan untuk membuat sistem kekebalan tubuh seseorang mampu mengenali dan dengan cepat melawan bakteri atau virus penyebab infeksi. Tujuan yang ingin dicapai dengan pemberian vaksin Covid-19 adalah menurunnya angka kesakitan dan angka kematian akibat virus ini. Dengan mendapatkan vaksin Covid-19, Anda tidak hanya melindungi diri sendiri, tapi juga orang-orang di sekitar Anda yang belum memiliki kekebalan terhadap virus Corona (Alodokter, 2021).

Proses vaksinasi sedang gencar-gencarnya dicanangkan pemerintah di Indonesia, namun luasnya wilayah di Indonesia mengakibatkan proses pemberian vaksin kepada masyarakat belum secara merata diperoleh terutama untuk warga masyarakat yang berada di daerah 3T termasuk di kabupaten Sumba Barat Daya. Melihat kondisi tersebut, STKIP Weetebula sebagai salah satu LPTK yang ada di wilayah kabupaten Sumba Barat Daya turut andil dalam proses percepatan pemberian vaksin Covid-19 di berbagai wilayah dan desa yang ada di Sumba Barat Daya termasuk di desa Pogotena.

Desa Pogotena merupakan salah satu desa yang termasuk dalam kecamatan Loura, kabupaten Sumba Barat Daya. Lokasi desa ini tidak jauh dari kota Tambolaka, namun sebagian besar warga masyarakatnya belum mendapat vaksin Covid-19. Kegiatan sosial ini dimotori oleh STKIP Weetebula dengan dukungan dan sponsor dari Salim Group yang memberikan bantuan dana untuk pelaksanaan vaksinasi masal untuk warga masyarakat yang ada di wilayah kabupaten Sumba Barat Daya.
Kegiatan sosial ini terintegrasi dalam kegiatan pengabdian yang dilakukan oleh dosen-dosen yang ada di STKIP Weetebula sebagai bentuk pengabdian dan kepedulian terhadap situasi dan kondisi yang sedang dihadapi oleh warga masyarakat. Vaksinasi massal ini sangat penting dilakukan agar masyarakat di berbagai daerah dan desa yang ada pada wilayah kabupaten Sumba Barat Daya yang belum terjangkau pelayanan vaksin Covid-19 dapat memperoleh kesempatan untuk divaksin. Dengan demikian, semakin banyak masyarakat yang memperoleh kesempatan untuk mendapat vaksin akan berdampak terhadap pemutusan rantai penyebaran dari Covid-19.

\section{Metode}

Kegiatan pengabdian ini dilaksanakan di Desa Pogotena yang terletak di Kecamatan Loura, Kabupaten Sumba Barat Daya. Kegiatan ini dilakukan oleh tim Dosen STKIP Weetebula bekerjasama dengan dinas Kesehatan Sumba Barat Daya dan Puskesmas Radamata yang pendanaannya didukung penuh oleh panitia bantuan vaksinasi Covid-19 Nasional dan juga Salim Group (Indofood, Indomaret, ACA Asuransi) serta Kemeterian Kesehatan Republik Indonesia. Adapun tahap pelaksanaan kegiatan ini dijabarkan seperti berikut ini.

\section{Penjajakan Desa Sasaran}

Pada tahap awal ini, dilakukan penjajakan terkait desa yang menjadi sasaran dan lokasi pelaksanaan vaksinasi Covid-19. Tahap ini dilaksanakan beberapa hari dengan melakukan wawancara kepada beberapa kepala desa untuk mendapatkan data atau jumlah masyarakat desa yang belum mendapatkan pelayanan vaksinasi baik tahap I maupun tahap II. Dari hasil wawancara beberapa desa terdekat, desa Pogotena menjadi desa terpilih untuk dijadikan desa sasaran karena banyak masyarakat yang belum mendapatkan vaksinasi dibandingkan dengan masyarakat desa lain. Pada tahap ini juga dilakukan penyebaran informasi kepada masyarakat desa melalui informasi lisan ke tingkat dusun dan RT/RW serta penyebaran informasi melalui media social seperti facebook dan Whatsapp Grup.

\section{Koordinasi Tingkat Dinas Kesehatan Sumba Barat Daya}

Pada tahap ini dilanjutkan dengan memberikan informasi terkait potensi desa sasaran dan jumlah warga yang menjadi sasaran pelaksanaan kegiatan kepada Dinas Kesehatan Sumba Barat Daya, yang selanjutnya diberikan tugas kepada pihak Puskesmas terdekat yaitu Puskesmas Rada Mata untuk melakukan pelayanan tersebut. Pada tahap ini juga dilakukan 
koordinasi terkait kebutuhan ruangan ideal serta fasilitas lain yang dibutuhkan oleh petugas serta melakukan koordinasi terkait kesiapan administrasi.

\section{Persiapan Lokasi Vaksinasi}

Berdasarkan inforamasi yang didapatkan saat tahap koordinasi, maka dilakukan persiapan lokasi vaksinasi yang memadai. Persiapan ini dilakukan sehari sebelum kegiatan pelaksanaan oleh tim dosen dibantu oleh beberapa mahasiswa dan aparat desa untuk melakukan pembersihan lokasi dan penataan ruangan serta menempelkan spanduk pada tempat yang telah disiapkan.

\section{Pelaksanaan Vaksinasi}

Vaksinasi terhadap masyarakat desa Pogotena dilakukan oleh Tim medis Puskesmas Radamata sesuai procedural medis dimana pada tahap pertama dilakukan registrasi peserta, briefing terkait efek samping dan hal-hal yang tidak boleh dilakukan oleh peserta vaksin setelah mendapatkan pelayanan, pengecekan kesehatan seperti pengecekan tensi dan menanyakan informasi lain tentang kesehatan untuk mendapatakan informasi terkait kesiapan tubuh peserta vaksin. Pada tahap ini, pengecekan tensi dan wawancara peserta vaksin serta penyuntikan vaksin dilakukan oleh tim medis, sedangkan tim Dosen dan mahasiswa membantu pada proses registrasi dan mobilisasi peserta vaksin.

\section{Hasil dan Pembahasan}

Dampak negatif yang paling menonjol dalam virus Corona adalah dibidang dengan kesehatan dan ekonomi. Hal ini juga sejalan (Taylor, 2019) yang menyatakan bahwa keberadaan virus Corona yang mengancam setiap orang berpeluang menjadi stressor bagi sebagian besar orang, dan dampaknya bisa jadi sama parahnya dengan dampak yang ditimbulkan jika terinfeksi virus Corona. Guna menekan kasus yang terus bertambah dan memulihkan kondisi ekonomi, Pemerintah pun menganjurkan agar semua orang mendapatkan vaksin COVID-19. Pemberian vaksin ini merupakan solusi yang dianggap paling tepat untuk mengurangi jumlah kasus infeksi virus SARS-CoV-2 penyebab penyakit COVID-19. Kondisi ini yang menggugah hati beberapa dosen dan mahasiswa yang ada di STKIP Weetebula untuk melaksanakan kegiatan sosial pemberian vaksinasi yang terintegrasi dalam kegiatan pengabdian kepada masyakat. Tujuannya adalah agar semua masyarakat mendapatkan vaksin secara merata tanpa terkecuali. Vaksinasi tidak 100\% bisa melindungi seseorang dari infeksi virus Corona namun pemberian vaksin dapat memperkecil kemungkinan terjadinya gejala yang berat dan komplikasi akibat COVID-19 (Zulaikha, Eliyana, \& Yun, 2021).

Capaian program kegiatan pengabdian Kepada Masyarakat ini adalah memberikan pelayanan vaksinasi Covid-19 kepada masyarakat Desa Pogotena. Kegiatan bakti sosial ini dilakukan berupa pendampingan serta penyuluhan pelaksanaan vaksinasi Covid-19. Kegiatan dilakukan pada Sabtu, 13 November 2021 bertempat di balai Desa Pogotena pukul 08.00 sampai 16.00 Wita. Pemberian vaksin dibantu oleh Tim medis puskesmas Radamata.

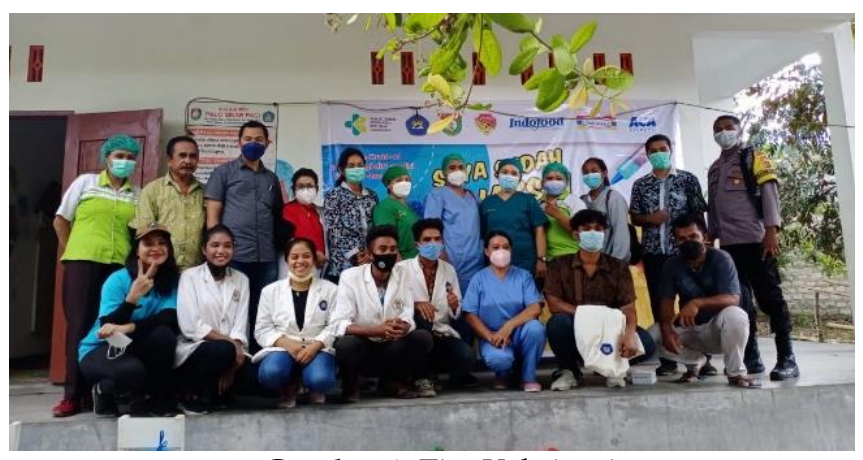

Gambar 1. Tim Vaksinasi

Vaksin berhasil diberikan kepada 156 orang yang memenuhi kriteria untuk divaksin. Pemberian vaksin covid-19 kepada masyakat bertujuan untuk meningkatkan imunitas tubuh agar pengurangi dampak penularan dan resiko virus (Rachmadi, Rahayu, Waluyo, \& Yuliyanto, 2021). Vaksin yang digunakan adalah AstraZeneca. Vaksin tipe ini memiliki metode memanfaatkan virus hasil modifikasi untuk membentuk antibodi. Selain itu juga vaksin ini ditujukan kepada usia 18 tahun keatas.

Vaksinasi diawali dengan pemberian edukasi singkat yang berkaitan dengan penyebaran Covid-19, proses pelaksanaan vaksinasi, syarat penerima vaksin dan efek samping yang ditimbulkan setelah vaksinasi. Edukasi berkaitan dengan virus covid-19 kepada masyakakat perlu dilakukan agar masyarakat paham dan mengerti bagaimana mencegah dan menghadapi kasus covid-19 (Istiatin, Marwati, \& Burhanudin., 2021)

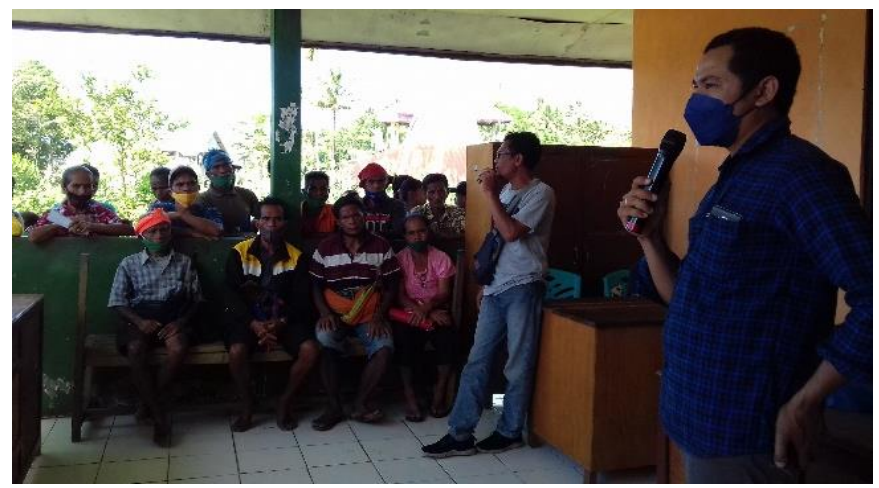

Gambar 2. Proses Edukasi kepada masyarakat 
Edukasi bertujuan untuk memberikan keyakinan kepada maskarakat bahwa vaksin covid aman untuk diberikan. (Gandryani \& Hadi, 2021) menyatakan masyarakat mempertanyakan efikasi dan efektivitas dan vaksin Covid-19 dengan dalih bahwa tidak efektif, isu konspirasi serta menimbulkan efek samping. Dalam proses edukasi singkat ini didapati beberapa alasan masyakarat belum mendapatkan vaksin yakni: (1) Keterbatasan obat vaksin yang ada di puskesmas terdekat; (2) Tempat vaksin yang jauh; (3) Memiliki penyakit bawaan sehingga memutuskan untuk tidak ke tempat vaksinasi tanpa berkonsultasi dengan pihak medis terlebih dahulu; (4) Takut dengan efek samping setelah vaksinasi sebab banyak rumor negatif yang beredar yang berkaitan gelaja yang dialami setelah vaksin; (5) Belum memiliki Kartu Tanda Pengenal atau Kartu keluarga.

Berdasarkan temuan tersebut maka menjadi landasan pemerintah dan semua kalangan masyarakat untuk memberikan edukasi positif agar proses vaksinasi bisa dilakukan secara merata. Vaksin COVID19 memang dapat membawa banyak manfaat untuk itu pastikan untuk selalu menjaga daya tahan tubuh atau imun dengan cara mengonsumsi makanan bergizi, rutin berolahraga, mengelola stres dengan baik, serta beristirahat yang cukup dan tetap menerapkan protokol kesehatan dimana pun dan kapan pun.

Setelah pemberian edukasi singkat kegiatan dilanjutkan dengan pendaftaran untuk memperoleh data calon penerima vaksin covid-19 yang dibutuhkan dalam tahap ini adalah KTP atau Kartu keluarga agar bisa mendapatkan informasi berkaian dengan Nomor Induk kependudukan calon penerima vaksin. Peserta yang mendaftar dalam kisaran 200-300 orang namun yang bisa dilayani untuk melakukan vaksinasi adalah 156 orang hal ini disebabkan oleh: (1) Jenis vaksin yang tersedia hanya AstraZaneca sehingga untuk pelayanan pendaftar dibawah umur 18 tahun tidak bisa terakomodir; (2) Pelayanan vaksin dosis 2 banyak yang tidak bisa dilakukan sebab calon penerima sudah melakukan vaksin pertama dengan jenis vaksin lain.

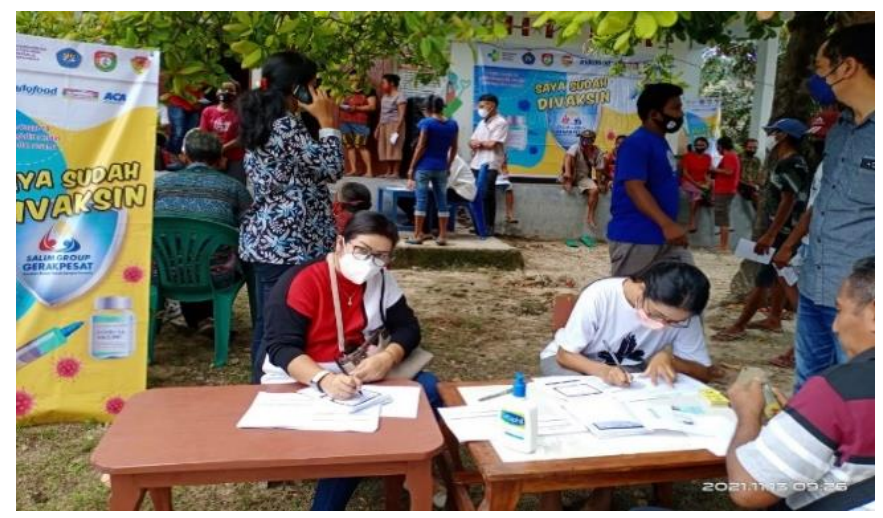

Gambar 3. Proses Penftaran Calon Vaksinasi

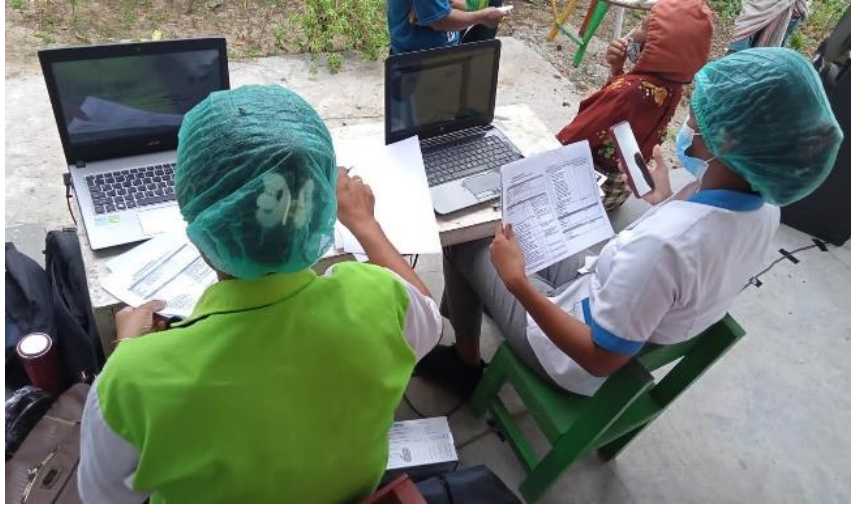

Gambar 4. Proses Verifikasi data

Kegiatan kemudian dilanjutkan dengan pemberian vaksin kepada masyarakat pogotena yang sudah terdaftar sebagai calon penerima vaksin.

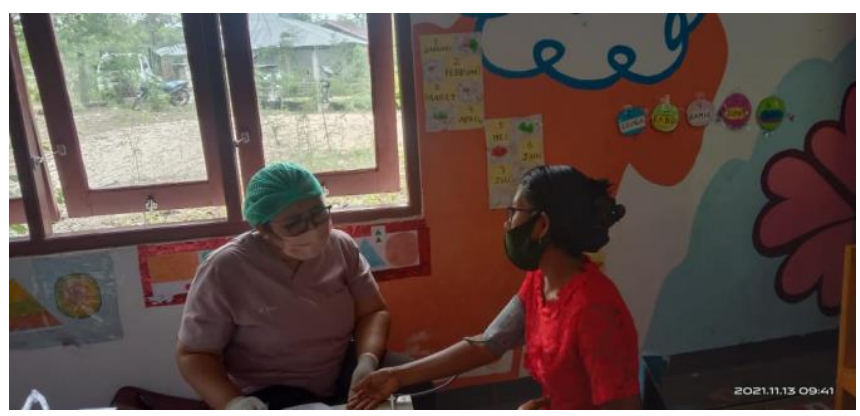

Gambar 5. Proses Pengecekan Kesehatan

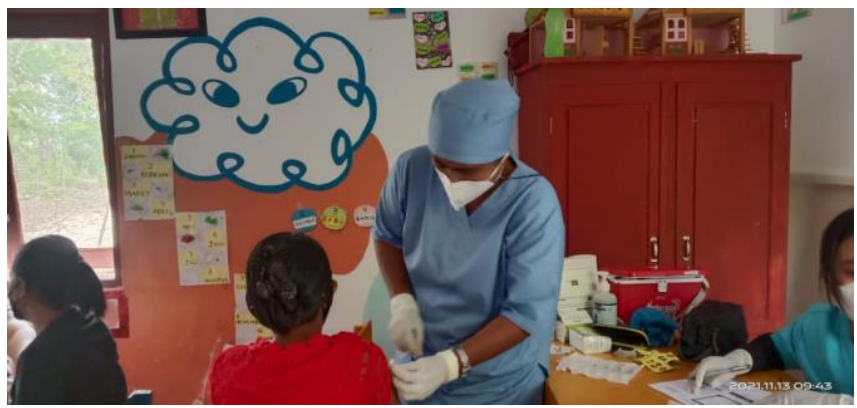

Gambar 6. Proses Vaksinasi

\section{Kesimpulan}

Kegiatan pengabdian kepada masyarakat yang dilakukan oleh tim dosen STKIP Weetebula berkolaboras dengan Dinas Kesehatan Sumba Barat Daya (Puskesmas Radamata) di Desa Pogotena yang disponsori secara penuh oleh Salim Group berjalan dengan baik dengan jumlah warga yang terlayani sebanyak 156 orang. Adapun jenis Vaksin yang dilayani adalah AstraZaneca untuk usia di atas 18 tahun. Pelaksanaan kegiatan ini diawali dengan adanya eduksi singkat terkait jenis vaksin dan efek samping dan halhal yang tidak diperbolehkan dilakukan oleh peserta setelah mendapatkan pelayanan tersebut. Dengan dilaksanakannya kegiatan ini menjadi harapan untuk 
terus menekan laju penyebaran Covid-19 yang secara tidak langsung pula akan berdampak pada leju pertumbuhan ekonomi yang kembali membaik dan bahkan lebih meningkat lagi.

\section{Ucapan Terimakasih}

Ucapan terimkasih pada pihak yang telah membantu penulis dalam pengabdian maupun publikasi ilmiah, termasuk donatur pengabdian yaitu panitia bantuan vaksinasi Covid-19 Nasional dan juga Salim Group (Indofood, Indomaret, ACA Asuransi) serta Kemeterian Kesehatan Republik Indonesia. Selain itu kepada, pimpinan STKIP Weetebula atas kesempatan yang diberikan kepada Tim untuk melaksanakan kegiatan Pengabdian kepada Masyarakat, dan juga untuk Missereor Jerman yang mendukung dalam publikasi hasil kegiatan pengabdian tim dosen.

\section{References}

Aladokter. (2021). Virus Corona. Retrieved from: https://www.alodokter.com/virus-corona

Gandryani, F., \& Hadi, F. (2021). Pelaksanaan Vaksinasi Covid-19 Di Indonesia: Hak Atau Kewajiban Warga Negara. Jurnal RechtsVinding, 10(1). http://dx.doi.org/10.33331/rechtsvinding.v10i1. $\underline{622}$

Istiatin, Marwati, F. S., \& Burhanudin. (2021). Sosialisasi Dan Edukasi Program Penanganan Dan Pencegahan Penyebaran Covid-19 Guna Meredam Kepanikan Sosial Di Wilayah Desa Gentan. Jurnal BUDIMAS, 3(2). http://dx.doi.org/10.29040/budimas.v3i2.2650

Rachmadi, T., Rahayu, T., Waluyo, A., \& Yuliyanto, W. (2021). Pemberian Vaksinasi COVID-19 Bagi Masyarakat Kelompok Petugas Pelayanan Publik di Kecamatan Buluspesantren. JURPIKAT (Jurnal Pengabdian Kepada Masyarakat), 2(2) https://doi.org/10.37339/jurpikat.v2i2.643.

Taylor, S. (2019). The Psychology of Pandemics: Preparing for the Next Global Outbreak of Infectious Disease. England: Cambridge Scholar Publishing.

Zulaikha, Eliyana, \& Yun, A. (2021). Pemberian Vaksin Sinovac Kepada Masyarakat Untuk Mencegah Penyebaran Covid 19. ANDASIH: Jurnal Pengabdian kepada Masyarakat, 2(2). 